\title{
EVALUATION OF PERMANENT RIVER ISLANDS OF EUPHRATES RIVER WITHIN KUFA-MISHKHAB SECTOR USING REMOTE SENSING APPLICATIONS, MIDDLE OF IRAQ \\ ${ }^{1}$ Wajeeh Hassan Sayhood ${ }^{*}$ and ${ }^{1}$ Muaid Jassim Rasheed \\ ${ }^{1}$ Department of Geology, College of Science, University of Baghdad. Baghdad, Iraq \\ "Email: wajeeh1970h@yahoo.com \\ Received: 23 January 2020; accepted: 18 February 2020
}

\begin{abstract}
River islands represent one of the important geomorphological features within the rivers streams that are formed by long and continuous moving of the waterway. Ten permanent river islands of Euphrates River within the Kufa-Mishkhab sector have been selected for studying and evaluating the geomorphological situations of the permanent river islands using remote sensing in the years 2002-2018. It was noted that the river islands of Euphrates River have been affected during those years in the river currents, as well as in both size and shape of the islands due to the extent of the river stream, low slope river floor, the curvature of the river, type of the lithological sedimentary formations and type of the sediments loaded.
\end{abstract} Keywords: Remote sensing; Geomorphology; Kufa-Mishkhab Sector; Euphrates River; Permanent river islands

\section{INTRODUCTION}

River islands represent one of the important geomorphological features within the rivers that are formed due to the long and continuous moving of the waterway, these islands formed either at the center of the river or near its banks. The river carries out the different sizes of sediments, and the slope is important in appeared and development of the island's river (Al-Ghurery, 2012). The river islands represent sedimentary forms formed by the matured river and aggregation of the sedimentary materials that increase and grow over time to become islands within the river canals (Karl, 1976).

The sedimentation process is the most important geomorphological process responsible for the river islands formation, as the river tends to sediment if the course of its course decreases significantly or if its section widens or if there is a curvature in the river course (Al-Ziyadi, 2017). The climate impacts (temperature, wind and rain) are one of the important natural factors responsible for formation and development of the terrestrial features in general and the river islands in particular, because of its impact on geomorphological and sedimentary processes. Because there are direct and indirect relationships between climate and these processes. (Al- 


\section{Iraqi Geological Journal Sayhood and Al-Khafaji $\quad$ Vol. 53, No. 1D, 2020}

Samurai, 2008). River islands represent one of the terrestrial forms that appear in most rivers, especially in the lower parts of the river. Their presence is associated with the lower capacity of the river to move parts of its load through its course. The low speed of the river, the higher the activation of river islands form. This process is often accompanied with natural factors within the river stream, leading to a decrease in the flow rate of the river, including, the lack of river slope, the amount of discharge, the amount of load and width or narrowness of the course, as well as the turning or straightening of the course, and the factors outside the flow is the climate (Al-Khalifawi, 2008). Especially temperature and rain, as temperatures work through the contrast between night, day, summer and winter on the destruction of rocks and dispersion, which facilitates the transportation by factors of erosion, such as wind and rain, and the high temperatures lead to loss of the river to large quantities of the water through evaporation or irrigation, which means the decline in the discharge rate and a lack of speed of the current. Unlikely, when the temperature decreases, the condition of the river in the first case of sediment more than in the second case, and rain, the impact appears by being a factor of erosion and weathering by contributing to increase the amount of transferred clastic coming from the floods that filled the abandoned valleys to the river course, and then becomes unable to afford such a load and resort to sedimentation (Al-Khalifawi, 2008).

The second factor includes the human factor as a geomorphological factor that is effective in changing the features of rivers, including dams, bridges and barriers, where it represents a suitable area to form river islands due to the decrease in river flow. Thus, the river islands represent a type of adaptation by the rivers, where large transported amounts of flooded sediments that increase in quantities over capacity and the size over its efficiency or the large cross-section compared to low discharge (Salama, 2004). Consequently, the current of the river is unable to carry most of its output, so that the larger deposits are deposited as sands when the flow rate of the river decreases, and finally these islands form. The river islands are formed in the riverbeds due to the combination of several factors (Al-Dulaimi, 2010): (1) The rise of the river load of the sediments, especially during the floods, (2) Low speed of the river flow for many reasons, including

A. Widening of the course. The existence of obstacles in river flow, whether natural or human to reduce the speed of flow and then increase sediments, such as the construction of bridges and dams on the rivers, which controlled the amounts of discharge and then the ability to carry the sediments, and helped to stabilize the islands in the rivers streams that fall after dams and bridges, and the inability of water through which the removal of the islands formed during the period of low levels. 


\section{Iraqi Geological Journal Sayhood and Al-Khafaji $\quad$ Vol. 53, No. 1D, 2020}

B. Presence of turns in the course of the flow, which works to make changes in the speed of the flow so as to increase in one hand and less on the other side of the course within the turn, so the sediments are concentrated on the one side and eroded on the other.

C. The confluence of the tributaries of the main course.

D. Entering the river into a lake or swamp leading to a low flow rate.

E. The sudden drop in river discharge.

From the above, we can summarize that the exceptional floods, especially the most severe ones, are able to develop the islands by adding thin layers of sand and other sediments. After sedimentation, these islands will become higher and thus the islands will tend to become permanent. It is worth noting that there is a direct relationship between the constituents of the banks and their viability for carving and transporting and the formation of islands, as the parts by which the course is expanded due to the processes of abrasion and transportation from the banks are then the opportunity to be the middle barriers in the course, and this can be attributed mainly to the slow flow due to the widening of the course, and finally, an island or more can be formed and the course is branched. The widening of the course after the expansion of the island through a decline in the original banks will help to increase the growth of river islands in this site from the stream. On the other hand, the growth of the island helps the decline of the banks and the reason is that the concentration of current lines will be greater on the original banks, thus leading to the phenomenon of collapse and landslides occurring on both sides of the course.

There are other reasons that led to the formation of river islands, such as the difference of the river drainage between one year and another is an important and effective factor in the formation and development of river islands. Drought periods are a good time to form islands, where the discharge and the water flow decrease that the load can't be transported by the flow, the current will deposit some of them to form the first nucleus of the island.

The increase in water discharge, i.e. the wet period of the year, may lead to an increase in the amount of the river load resulting from increasing of erosion activity and the abrasion of sediments that descend into the stream, leading to an increasing in the river load level exceeds the capacity of it, thus it uses its deposition for the load in places where the nucleus evolves by the time to the island (Al-Tahiri \& Hussein, 2011).

\section{STUDY AREA}

The study area is located in the central part of Iraq and it is a part of the Mesopotamian plain. It lies within Al-Najaf Governorate, and it represents a part of the Euphrates River which extends from Kufa Dam (North of Kufa) to Al-Mishkhab Dam (South of Al-Mishkhab). The 
study area covers $6500 \mathrm{~km}^{2}$, located between the latitude $32^{\circ} 06^{\prime} 6.14^{\prime \prime}$ and $31^{\circ} 79^{\prime} 4.08^{\prime \prime} \mathrm{N}$ and longitude $44^{\circ} 21^{\prime} 3.52^{\prime \prime}$ and $44^{\circ} 50^{\prime} 19.2^{\prime \prime}$ E, as shown in Figure (1).

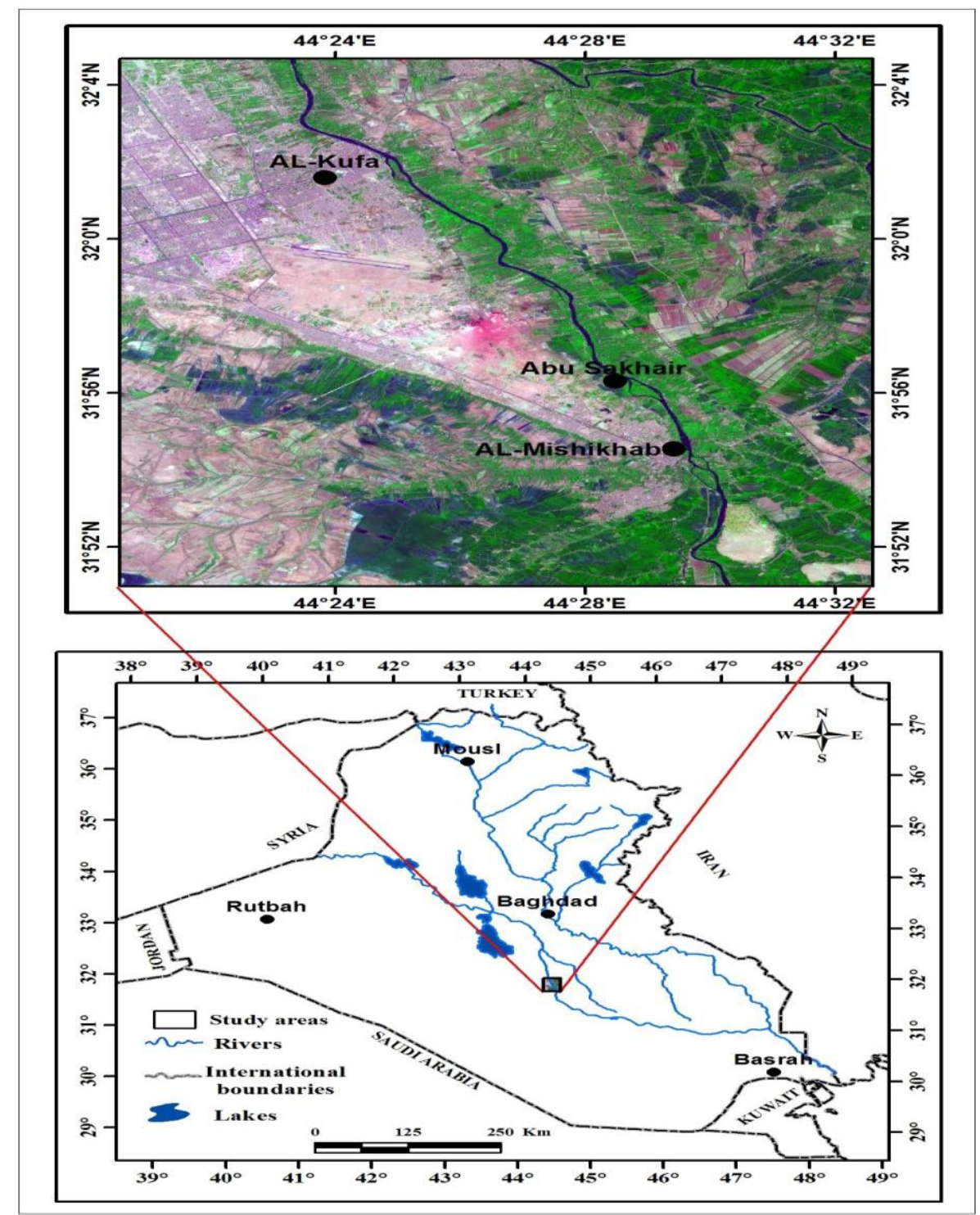

Fig. 1. A satellite image shows the location of the study area

\section{DATA AVAILABILITY}

The fieldwork was carried out during the period 24/11/2018 to $14 / 1 / 2019$, at this stage a complete and more accurate explanation of the preliminary information obtained on the previous stage on the area, specifically the geomorphological manifestations. Any geomorphological field study represents a spatial case study as detailed as possible, so fieldwork is a reality that requires understanding and interpretation through frequent visits to the study area. On the other hand, ArcMap GIS software, version 10.4 has been used to evaluate and understand the difference of the permanent river islands within the Kufa-Mishkhab sector 


\section{Iraqi Geological Journal Sayhood and Al-Khafaji $\quad$ Vol. 53, No. 1D, 2020}

from the years 2002 and 2018 using Land Sat-7 and Land Sat-8 images by companions of band1, band-2, band-3, band-4, band-5, and band-6. The results of the fieldwork detected six

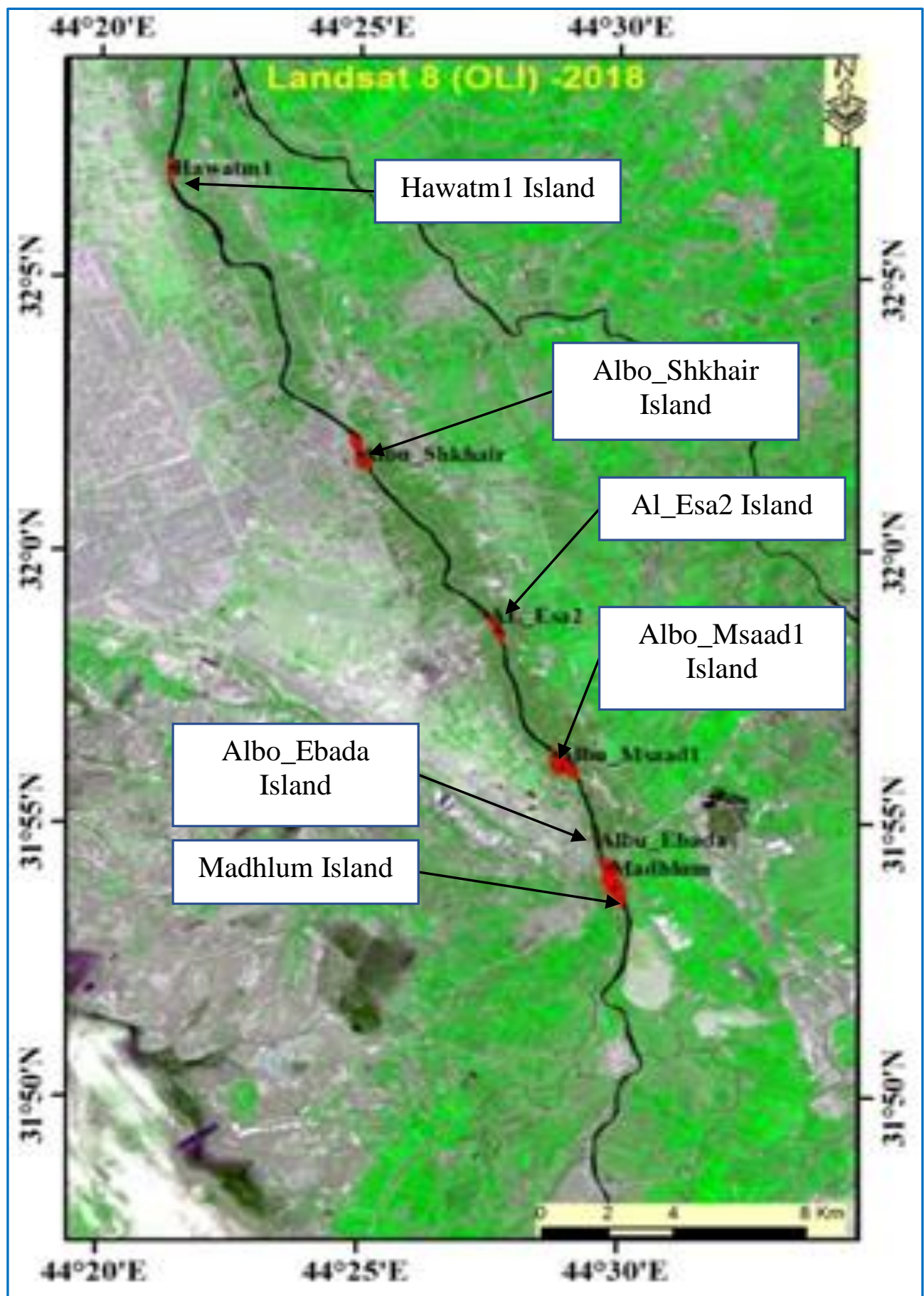

permanents river islands of Euphrates River within Kufa-Mishkhab sector (Fig. 2).

Fig. 2. The permanent river islands of Euphrates River within Kufa-Mishkhab sector

Generally, there are two main types of river islands, the first extends longitudinally with the direction of the course and is called the longitudinal islands. The second is located in the middle of the course to transect it and it is called the transversal islands. The river islands are 
formed around a nucleus, and after their appearance on the surface of the water almost permanently, only extreme floods can submerge their peaks or developing them by adding a thin layer of clastic and after deposition make these islands higher above the level of the water surface of the stream and so in the successive exceptionally severe floods, the islands gradually built horizontally and vertically by the sedimentation of the clastic (Gad, 1981).

\section{RESULTS AND DISCUSSIONS}

In many cases, there is a consolidation between the river islands and one of the sides of the nearby course due to several reasons, the most important of which is the large size of the clastic brought by the river during floods. In the study area, the river islands in 2018 are the following:

1. The islands vary in area, that ranging from $342439 \mathrm{~m}^{2}$ in Al-Bakhatra and $10032 \mathrm{~m}^{2}$ in Albu-Ebada, as in Table (2) and Figures (3\&4).

2. The difference of islands in the distance from the nearest bank, some are close and separated from the bank only a few distances, as in the islands (Albu_Msaed2 and Abd_Hwaidi), which is separated from the left bank only (10) $\mathrm{m}$.

3. The islands take different forms. Some of them extend parallel to the length of the course (longitudinal), while others are (oval or circular), in addition to their different location from the bank, whether right, left or middle of the course (Fig. 5.)

\begin{tabular}{|l|c|c|c|}
\hline \multicolumn{1}{|c|}{ Name } & Area $\mathrm{m}^{2}(2002)$ & Area $^{2}(2018)$ & Side \\
\hline Albu_Shkhair & 284944 & 218170.0 & Center \\
\hline AL_Esa3 & 114193 & 96411.2 & Right $20 \mathrm{~m}$ \\
\hline AL_Esa2 & 13217 & 38723.0 & Right 50m \\
\hline Albu_Msaed2 & 290859 & 278373.0 & Right $10 \mathrm{~m}$ \\
\hline Albu_Msaed1 & 43249.4 & 40158.7 & Right 20m \\
\hline AL_Bakhatra & 374273 & 342439.0 & Right $40 \mathrm{~m}$ \\
\hline Madhlum & 157394 & 146091.0 & Left 40m \\
\hline Hawatm1 & 29174.8 & 83009.0 & Left 20m \\
\hline Abd_Hwaidi & 9034.22 & 13724.0 & Right $10 \mathrm{~m}$ \\
\hline Albu_Ebada & 14935.7 & 10032.0 & Right $15 \mathrm{~m}$ \\
\hline
\end{tabular}

Table 1. The area of the permanent river islands of Euphrates River

within Kufa-Mishkhab sector 


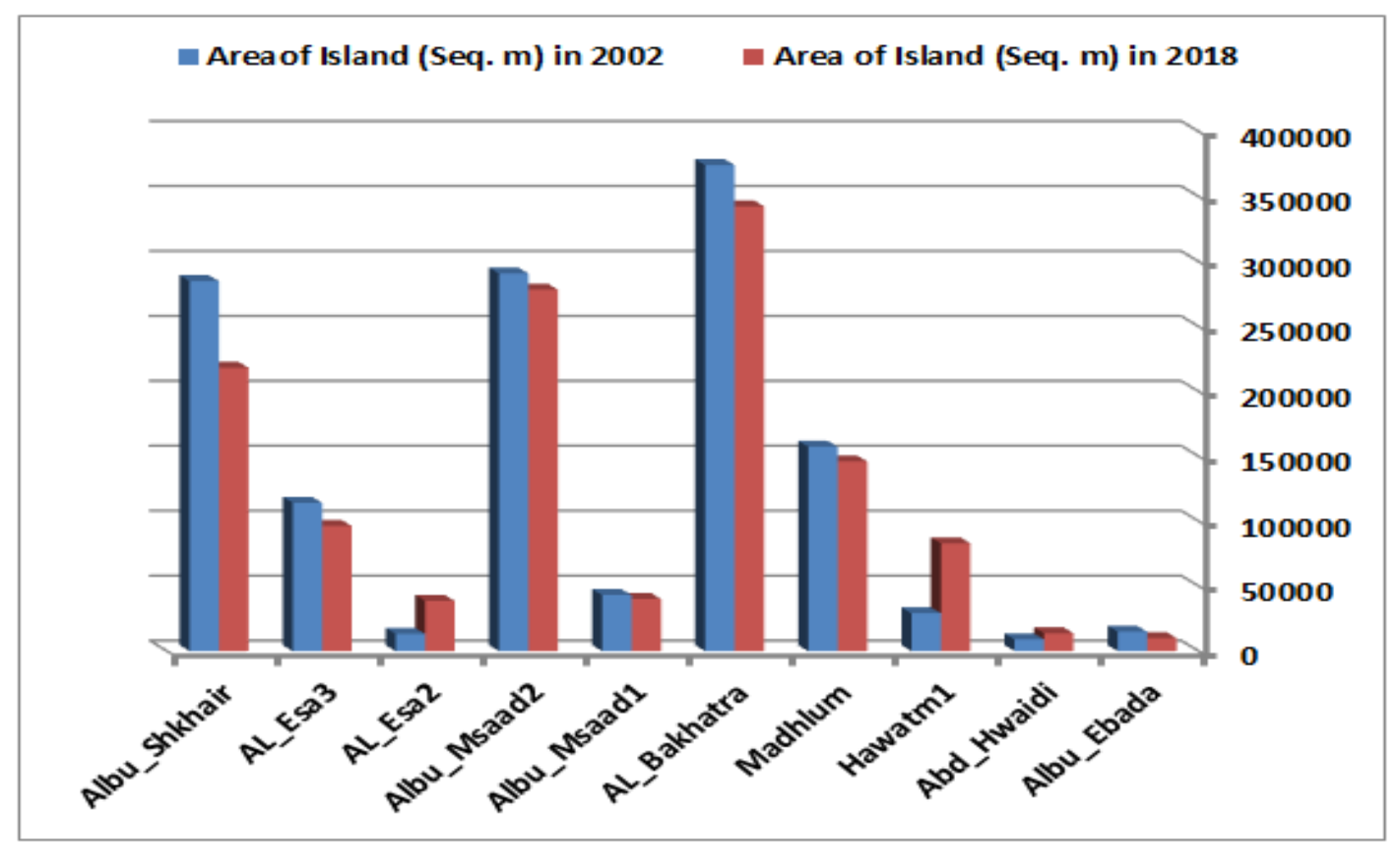

Fig. 3. Compares between the area of the permanent river islands in the study area at years of 2002 and 2018

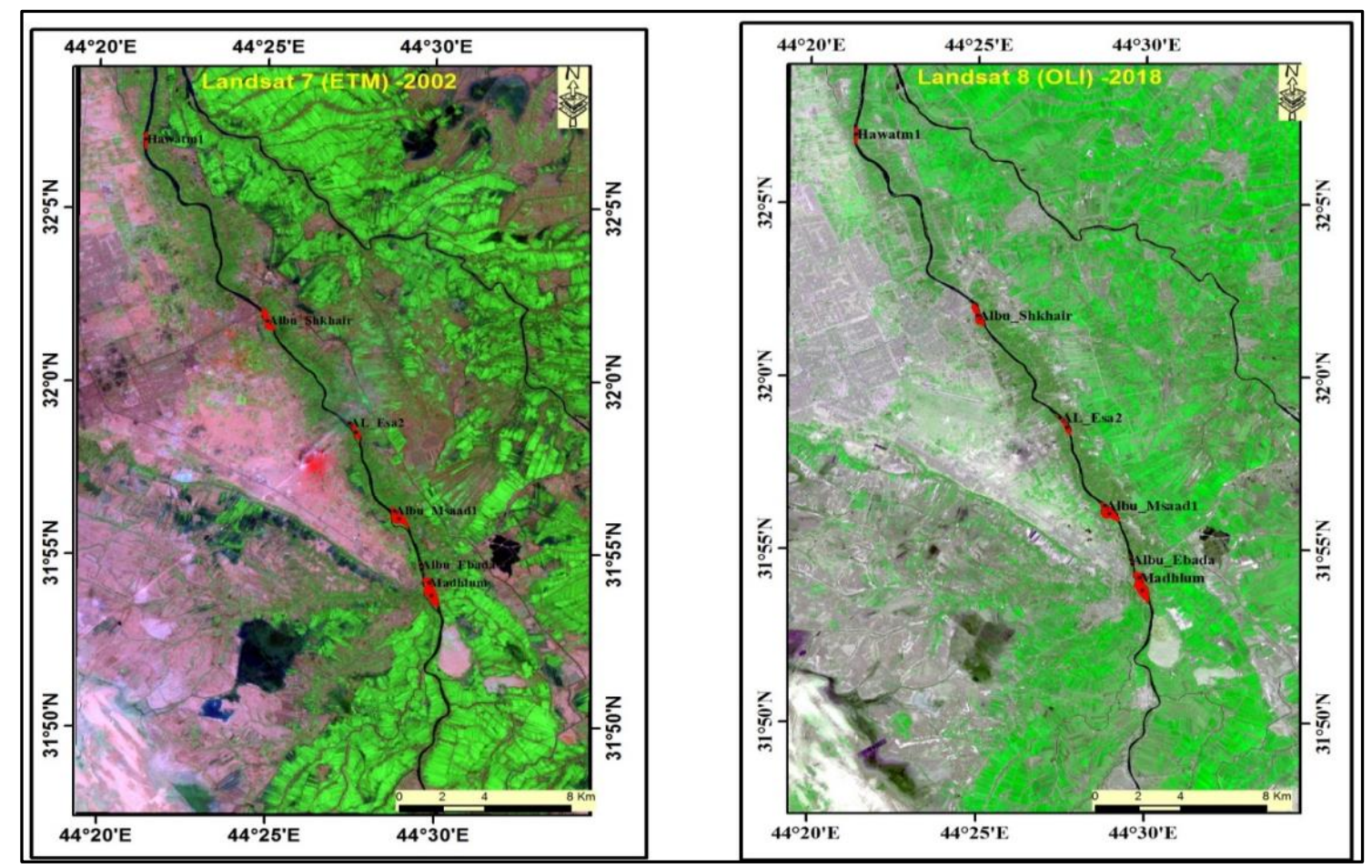

Fig. 4. The permanent river islands of Euphrates River within Kufa-Mishkhab sector at 2002 and 2018

4. Some of the islands that were diagnosed in the study area appear close to the right bank of the river and at a distance of $10 \mathrm{~m}$, such as (Albu-Msaed2 and Abd_Huwaidi islands) and is expected to consolidate this nearby bank with the continuation of the geomorphological processes of the river and 
speed of the weathering resulting in large sedimentation on one hand, and after the occurrence of this situation will naturally lead to the activation of the processes of the left bank of the river (the opposite bank), while sedimentation operations activate at the right bank of the river, according to the erosional and sedimentological stream cycle for the water course in general and the river section at the location of consolidating the island with one of the river banks. In particular, which is expected to cause the emergence of a new river meander in these areas as for that one the other hand, continuing the geomorphological fieldwork of the river. The same things happen with (Hawatm1 and Madhlum) islands that are lying on the left bank of the river.
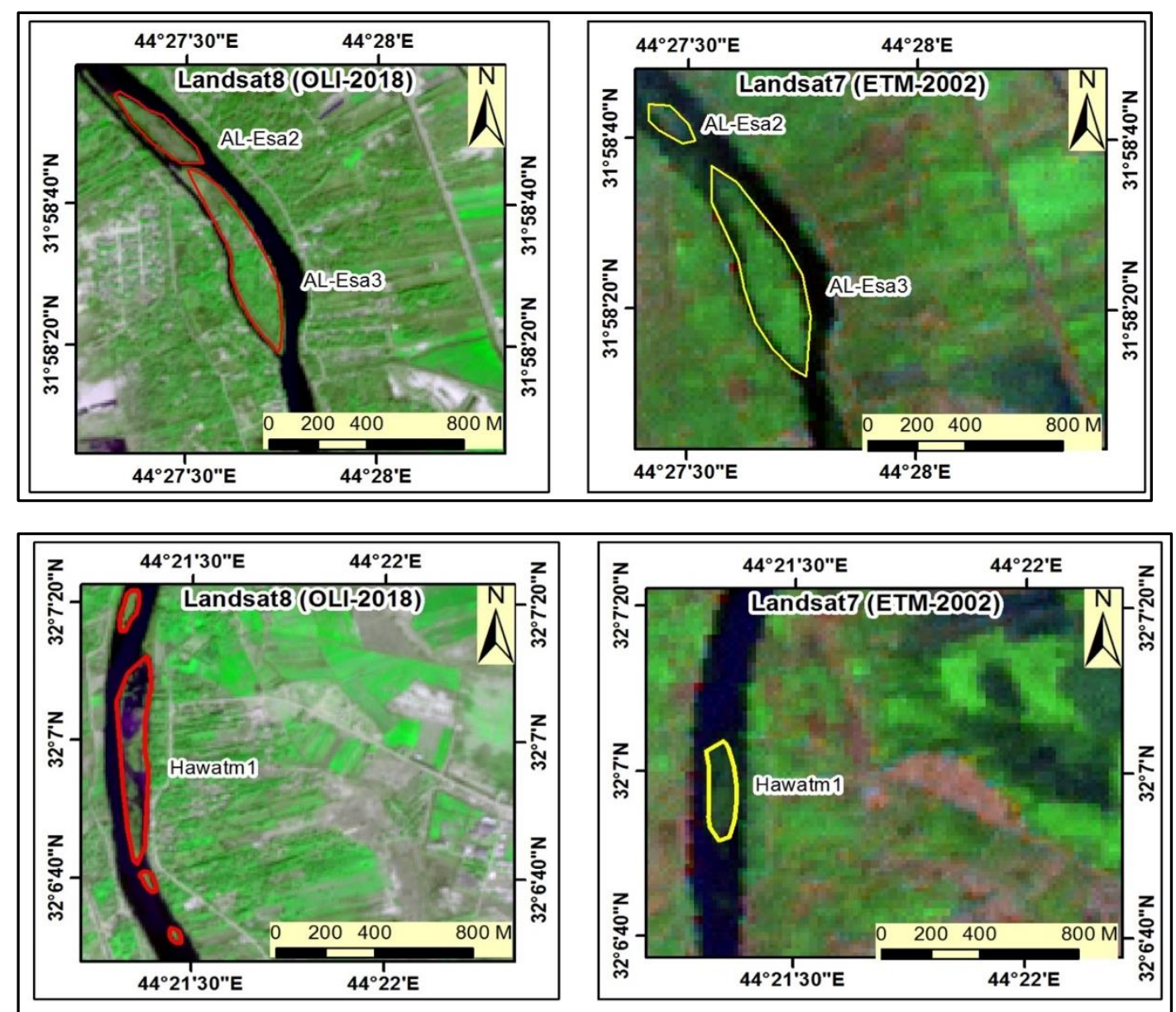

Fig. 5. Different in river islands of the study area and comparing it with 2012 and 2018 years 

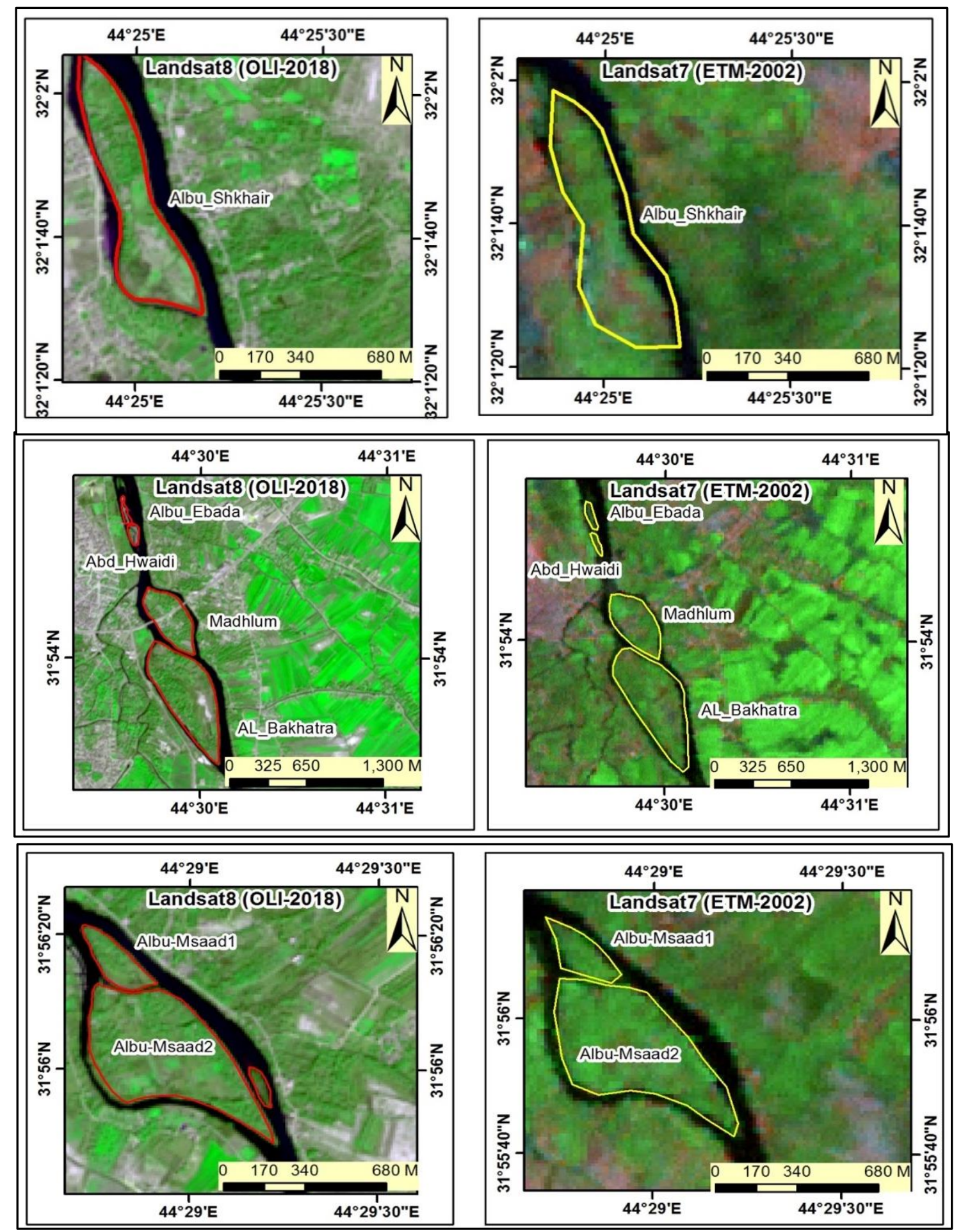

Fig. 5. Continue................

\section{CONCLUSIONS}

The satellite images and field studies of the Kufa-Mishkhab sector in the Euphrates River show the presence of 10 islands that are varying in areas, shapes, and the distance from the banks. The river islands have been developed based on the location within the water stream, sediment content discharge, and river slope. Some island parts have been eroded and the results carrying 


\section{Iraqi Geological Journal Sayhood and Al-Khafaji Vol. 53, No. 1D, 2020}

out within the stream to deposited at the front of the next islands, based on these results the satellite images confirm the sedimentation activity which leads to the construction and development of the river islands in terms of increasing their sizes and areas. Some island parts are characterized by increasing the sedimentation activity on the front side of the island due to the river obstructions such as bridges.

\section{REFERENCES}

Al-Dulaimi, A. H. K., 2010. The applied of the earth science shape ${ }^{1 s t}$ Edition, Dair Al-Saffia for printing and publishing, Jourdan.

Al-Ghurery, A. Y., 2012. Geomorphology of Al-Diwaniyah river Stream between Sunni and Diwaniyah, Journal of The Thi Qar Arts, Vol: 2, No:8, pp. 287-327. (In Arabic).

Ali, J. A., and Saadallah, A., 1990. The Sedimentlogy, Dar Al Hekma Press, Baghdad, Iraq. (In Arabic).

Al-Khalifawi, R. M. K., 2008. The River Islands of the Euphrates River (Geomorphological study), unpublished Ph.D. thesis, College of Education, Al-Mustansiray university. (In Arabic).

Al-Samurai, A. Q., 2008. The impact of the increase in the amount of rain falling in northern Iraq, Professor Journal, 71: 174. (In Arabic).

Al-Tahiri, R., and Hussein, J., 2011. Bifurcation Phenomenon of Euphrates River Course in Al-Kufa And AlAbassiyah Tributraries Between Kifl And Shinafiyya, Unpunished M.Sc. Thesis, College of Arts, University of Al-Baghdad, P.99. (In Arabic).

Al-Ziyadi, E.A., 2017. Geomorphology of River Islands in the Euphrates Stream Between the Cities of Nasiriyah and Qurna using GIS, unpublished M.Sc. thesis, College of Education for Humanities, University of Basra. (In Arabic).

Gad, M. T., 1981. Geomorphological characteristics of the flood plain river with a study on the Nile in Middle Egypt, Kuwait Geographic Society,32. (In Arabic).

Karl, W. B., 1976. Geomorphology from The Earth, Harper and Row, Publishers, New York, 155pp.

Salama, R. H., 1982. The Geomorphological shape and it is characteristics. Kuwaiti Geographic Society, 43: 5. 